\title{
Influence of deficit irrigation in enhancing the Postharvest quality of vegetables
}

\author{
Mahendranthan C.1 \\ chandrakantha@esn.ac.lk \\ Department of Botany, Eastern University, Sri Lanka
}

\begin{abstract}
Deficit irrigation (DI) is an agricultural water management strategy by which crops are exposed to a level of drought stress either during a certain period of time or during the entire growing season. DI in peppers (Capsicum annuum L.) reduces the fresh weight of the harvested fruits. However, the results also proved that DI from flower initiation to fruit harvest lead to better water use efficacy of pepper cultivars, particularly Cv. Marconi Rosso. Further, the results proved that the postharvest quality, importantly the health-benefitting properties of peppers can be enhanced through the water-stress treatment. It leads to more accumulation of sugars as a mechanism to reduce the osmotic potential of the water-stressed plants. Similarly, the phenolic content, reported to have number of health benefitting properties, was also increased in all three cultivars of peppers with the deficit irrigation practice, under glass house condition.
\end{abstract}

Key words; Capsicum annuum, Deficit irrigation, postharvest quality, health benefits.

\section{Introduction}

Bell peppers (Capsicum annuum L.) are the most important vegetable spice grown in the tropical and subtropical regions of the world because of their color, taste, pungency, flavor and aroma (Fallik et al., 2019; Rocha et al., 2018). They are used as an exhauster of peppery taste and the capsicum fruit are known for their flavor and burning sensation in the mouth (Rocha et al., 2018). 
On the other hand, global warming could be a challenge and can have the impact in the available water. This creates climate changes that substantially affect the timing and volume of water availability in many regions. Hence, dealing with reduced water supply becomes vital, even after the adoption of water efficiencies achieved. This has prompted the implementation of strategies to optimize production of both land and water resources (Abu Glion et al., 2019). One of the consequent approaches has been the adoption of deficit irrigation. This deficit irrigation water management technique involves applying a lesser volume of water at each irrigation event for the entire irrigation season (Venturi et al., 2021), especially the economical and sustainability aspects of the practice. They have showed increases in water productivity with deficit irrigation and general sustainability in farm incomes where practiced.

Thereby, the present study was carried out to apply the deficit irrigation during the growth of three different sweet pepper cultivars, namely Friggitello, Marconi Rosso and Pepperone under greenhouse growing conditions. The objectives of this study were to assess the response of three different sweet pepper (Capsicim annuum) cultivars, namely Friggitello, Marconi Rosso and Pepperone to impose water-deficit irrigation under greenhouse conditions and to determine the effect of deficit irrigation on the phytochemical properties of these pepper cultivars, with special reference to phenolics and soluble sugars.

\section{Material and Methods}

\subsection{Plant material and growth conditions}

Pepper seeds (Capsicum annum L.) Cvs. Friggitello Marconi Rosso and Pepperone were germinated on the $2^{\text {nd }}$ of April, 2009 and grown under glasshouse conditions at Cranfield University (Cranfield, Bedford, UK), with a $14 \mathrm{~h}$ photoperiod, $22 \pm 2{ }^{\circ} \mathrm{C}$ (day)/18 ${ }^{\circ} \mathrm{C}$ (night) and a relative humidity of $48 \pm 56 \%$. After 5 weeks, seedlings were carefully transferred to $5 \mathrm{~L}$ capacity pots containing John Innes No. 2 compost. The total nitrogen concentration of the compost substrate was $8.88 \mathrm{~g} \mathrm{~N} \mathrm{~kg}^{-1}$, as determined by Kjeldahl analysis. Plants were grown in rows $1 \mathrm{~m}$ apart, with $0.5 \mathrm{~m}$ spacing between plants within rows, giving a plant population of 2 plants $\mathrm{m}^{-}{ }^{2}$. Plants were fertilized regularly with a full strength Hoagland nutrient solution. Plants were supported vertically by $3 \mathrm{~m}$ long stick to keep them upright, and were allowed to grow naturally without restricting the stem number.

\subsection{Irrigation treatments}

A completely randomized design was adopted with each of 4 blocks containing 36 plants ( 3 cvs. $\times 4$ replicates $\times 3$ treatments $=36 \times 3$ blocks $=108$ ). Water treatments were started at the stage of most of the primary fruits from the primary truss was at flower initiation stage. 
Prior to commencing water treatments, plants were kept at or near field capacity (ca. $0.79 \mathrm{~m}^{3}$ of water per $\mathrm{m}^{3}$ of soil) for approximately three weeks. The treatments were applied in three different categories: $\mathrm{T} 1$, watered with $400 \mathrm{ml}$, (100\% of the estimated crop water requirements); T2, watered with $200 \mathrm{ml}$ (50\% of the water applied to T1) and T3, watered with $100 \mathrm{ml}$ (25\% of the water applied to T1). Plants were sprayed with Proplant (fargro®; Propamocarb hydrochloride $62.9 \% \mathrm{w} / \mathrm{w}$ ) to control the root rot caused by Phytophthora spp. Flowers were hand-pollinated with a sable paintbrush to minimize the occurrence of misshapen fruit.

\subsection{Soil moisture Content and Environmental monitoring}

Soil moisture content was $\left(\mathrm{m}^{3}\right.$ water per $\mathrm{m}^{3}$ of soil) was Measured every day (ca. 16:00 h) with the help of time-domain-reflectometry (TDR) using a Thetabrobe (Thetakit type TK3, Delta-T Device, cambs., UK). The water holding characteristics for the growing medium were determined and the $\mathrm{mV}$ reading was converted to $\mathrm{m}^{3}$ water per $\mathrm{m}^{3}$ of soil using an equation derived form a calibration curve from a data set taking the $\mathrm{mV}$ reading $(206-995 \mathrm{mV})$ corresponding to the volume of water in a soil sample $(0.0502$ $0.2826 \mathrm{~m}^{3}$ per $\mathrm{m}^{3}$ of soil). The equation was $\mathrm{y}=2.6727 \mathrm{x}+133.85$. Hourly temperature within the glass house was recorded throughout the season using two Delta-T data loggers, each scheduled from solar radiation by a polythene cup. Mean temperature inside the glasshouse during the growing period was $21^{\circ} \mathrm{C}$.

\section{4. $\quad$ Fruit sampling}

Two first primary fruits, one from each branch of the secondary truss of each plant, were harvested and therefore 72 fruits were harvested from each water stress treatment $(n=216)$. However, given the incidence of blossom end rot, the total number of the harvested fruits were 180. Among the lost fruits, nineteen corresponded to the lowest water treatment (T3), eleven to $\mathrm{T} 2$ and the rest to $\mathrm{T} 1$. The initiation of colour change from green to red was considered as the fully matured stage for harvesting. The objective colors of fruits were measured separately using a Minolta CR-400 colorimeter and DP-400 data processor (Minolta Co. Ltd., Japan) with an $8 \mathrm{~mm}$ light-path aperture. Calibration of this instrument was done with a Minolta standard white tile CR- $400(Y=93.48, x=0.2870, y=0.3376)$. The mean of three readings at three equidistant points $(n=9)$ around the equatorial axis was recorded and the lightness $\left(\mathrm{L}^{*}\right)$, chroma (color saturation; $\mathrm{C}^{*}$ ), and hue angle $\left(\mathrm{H}^{\circ}\right)$ were automatically calculated (Ferreira et al., 2017). These harvested fruits were weighed and individually prepared immediately for biochemical analysis.

\subsubsection{Blossom-end rot score}


Observations were made for Blossom End Rot (BER) incidence and severity during each harvest. Incidence of this physiological disorder was calculated as percent fruits showing any size of lesion of BER. Severity of this disorder was calculated by measuring the average diameter of the lesion and comparing it to the diameter of the fruit (Cui et al., 2020).

\subsubsection{Sample Preparation and Reagents.}

Fruits without calyxes were cut into small pieces and were snap frozen immediately in liquid nitrogen. Samples were stored at $-40{ }^{\circ} \mathrm{C}$ and were freeze-dried in an Edwards Modulyo freeze drier (W. Sussex, UK) for 10 days at $0.15 \mathrm{mBar}$. Lyophilized samples were then ground using a mortar and pestle, weighed, and were stored again in the freezer until use. All reagents used, were purchased from Sigma (Dorset, UK) unless otherwise stated.

\subsubsection{Extraction and Quantification of Sugars}

Freeze-dried samples were used for sugar analysis. Extraction was carried out using 62.5\% (v/v) aqueous methanol as the extraction solvent. That is; $150 \mathrm{mg}(\mathrm{n}=72$ fruits per DI treatment; excluding missing fruit) samples of each fruit, were mixed with $3 \mathrm{~mL}$ of this methanol solvent. In order to assure the better extraction, these samples were placed in a shaking water bath at $55^{\circ} \mathrm{C}$ for $15 \mathrm{~min}$, vortexing the samples every 5 minutes to prevent the layering. Then samples were left to cool and were filtered through a $0.2 \mu \mathrm{m}$ Millex-GV syringe driven filter unit (Millipore Corporation, MA). The obtained clear extract was used for Non Structural Carbohydrates (NSCs) analysis. The NSC content in pepper extracts was determined using a HPLC system comprising a P580 pump, and GINA 50 auto sampler (Dionex, CA) (Ferreira et al., 2017). For the analysis of soluble sugars, $20 \mu \mathrm{L}$ of diluted pepper extract (1:10), was injected onto a Rezex RCM monosaccharide $\mathrm{Ca}+$ column, $300 \mathrm{~mm} \times 7.8 \mathrm{~mm}$ diameter, $8 \mu \mathrm{m}$ particle size (Phenomenex, CA; Part no. 00H-0130-K0), with a Carbo-Ca+ guard column, $4 \mathrm{~mm} \times 3 \mathrm{~mm}$ diameter (Phenomenex, CA; Part no. AJ04493). The HPLC grade water was used as the mobile phase with the flow rate of $0.6 \mathrm{mLmin}-1$. The column temperature was adjusted to $75^{\circ} \mathrm{C}$ using a Dionex STH column thermostat. Eluted sugars were detected by an evaporative light scattering detector (ELSD 2420, Waters, MA) connected to the Dionex system using a UCI-50 universal chromatography interface. The quantity of fructose, glucose, and sucrose found in the pepper samples, were automatically calculated by comparing sample peak area to standards using Chromeleon version 4.6 software (Dionex).

\subsubsection{Extraction and Quantification of Total Phenolics.}

Freeze-dried pepper samples (150 mg; $\mathrm{n}=72$ fruit per DI treatment) were dissolved in $3 \mathrm{~mL}$ of $80 \%$ aqueous ethanol solvent and were placed in a water-bath for $2 \mathrm{~h}$ at $70{ }^{\circ} \mathrm{C}$. Samples were mixed at mixed at every 20 min. to avoid layering. Then the samples were kept until cool and were filtered through a $0.2 \mu \mathrm{m}$ Millex-GV syringe driven filter unit (Millipore Corporation, MA). Total phenolics were measured 
according to the Folin-Ciocalteu method (Malejane et al., 2017), based on the reduction of a phosphowolframate-phosphomolibdate complex by phenolics to blue reaction products. That is, $20 \mu \mathrm{L}$ of filtrate and $3.2 \mathrm{~mL}$ of distilled water were mixed with $200 \mu \mathrm{L}$ of Folin-Ciocalteu's phenol reagent, followed by $600 \mu \mathrm{L}$ of sodium carbonate $(1.9 \mathrm{M})$. This was incubated in the dark for $2 \mathrm{~h}$ at room temperature $\left(20{ }^{\circ} \mathrm{C}\right)$. Finally, absorbance was measured at $760 \mathrm{~nm}$ using a Camspec M501 UV/vis spectrophotometer (Camspec Ltd., Cambs., UK). The phenolic content was calculated using a standard curve of the gallic acid The results were expressed as mg of gallic acid equivalents (GAE) $100 \mathrm{~g}^{-1} \mathrm{DW}$.

\section{Results}

\subsection{Soil water status}

Volumetric water content of soil media (compost) differed between all DI treatments (Fig.3.1. a, b and c.) as well as between the cultivars. However, the non-DI-treated plants showed consistent values in the soil water content and it ranged from 0.79 to $0.77 \mathrm{~m}^{3}$ of water per $\mathrm{m}^{3}$ in all three cultivars. As expected, the rate of decline in soil-water content was greater for plants treated with $100 \mathrm{~mL}$ of water per day than in plants receiving $200 \mathrm{~mL}$ water per day. Plants from Cv. Marconi Rosso, grown under drought stress conditions used more water (up to $15 \%$ more) from soil medium during the first days after commencing water treatments than the rest of cultivars (3.1).

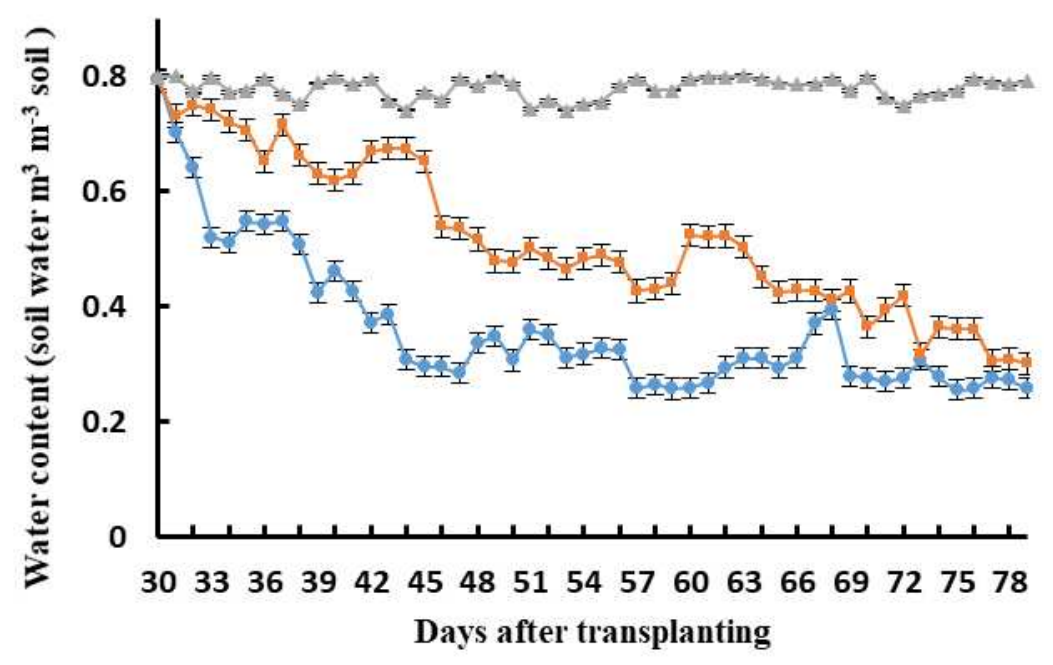

(a) 


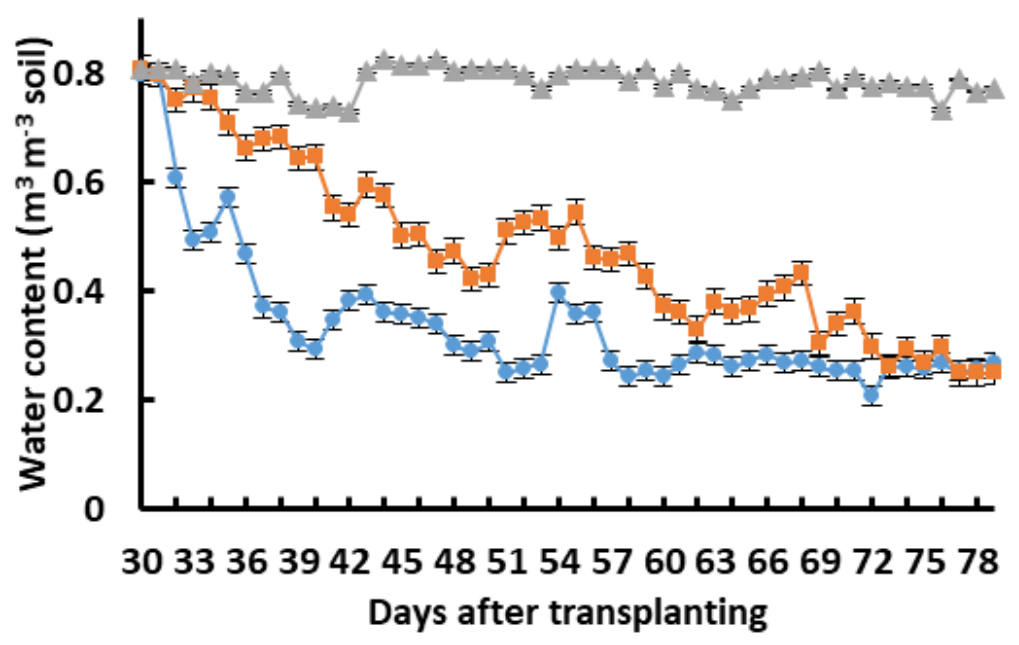

(b)

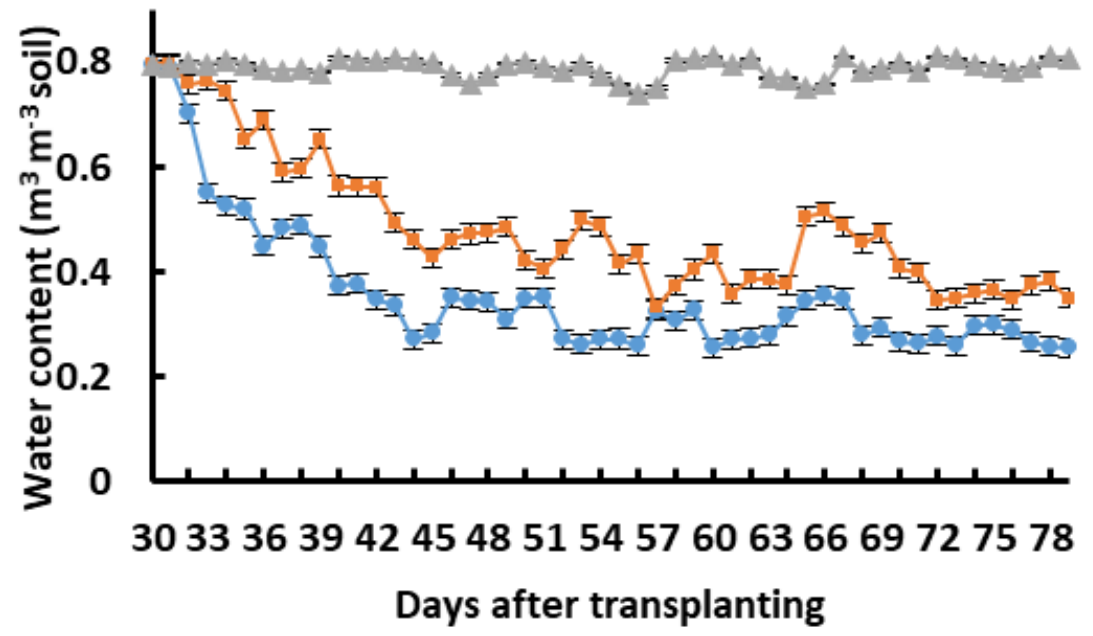

(c)

Fig. 3.1. The water volume of the growing medium of three different pepper plant cultivars, Friggitello (a), Marconi Rosso (b) and Pepperone (c) grown under deficit irrigation, with rates of 100 (circle), 200 (square) or fully irrigation, $400 \mathrm{~mL}$ (triangle) of water per day and watered daily before 09:00 h measured at ca. 16: $00 \mathrm{~h}$ (4 p.m.). Error bars indicate LSD $(\mathrm{P}<0.05)$ values for the daily interaction cultivar * water treatment. LSD $(\mathrm{P}<0.05)$ value for the overall interaction days *cultivar * water treatment was 0.25 .

\subsection{Effect of DI on fruit physiology}

The results indicated that water stress influenced the fresh weight (FW) and dry weight (DW) of the fruits 
(Fig.3.2. a \& b). When considering cvs. Marconi Rosso and Friggitello, fruits from fully irrigated plants (400 mL of water per day), were nearly $1.2-1.8$ fold heavier (42.72-50.87 g) than fruit from plants treated with $200 \mathrm{~mL}$ (29.54 -32.78 g) or $100 \mathrm{~mL}$ of water per day (26.75 -28.57 g). Whereas, in cv. Pepperoni, FW and DW of water stressed and non-stressed plants did not differ significantly. Nevertheless, the dry weight, as a proportion of fresh weight was significantly higher for fruit from cvs. Friggitello and Marconi Rosso, that showed the reduced fruit weight and treated with less water than the control, $400 \mathrm{~mL}$ (Fig.3.2.b). Further, fruits from cv. Pepperone showed the greatest increase (1.49-fold higher) in dry matter content as a proportion of fresh weight in response to reduced water treatment.

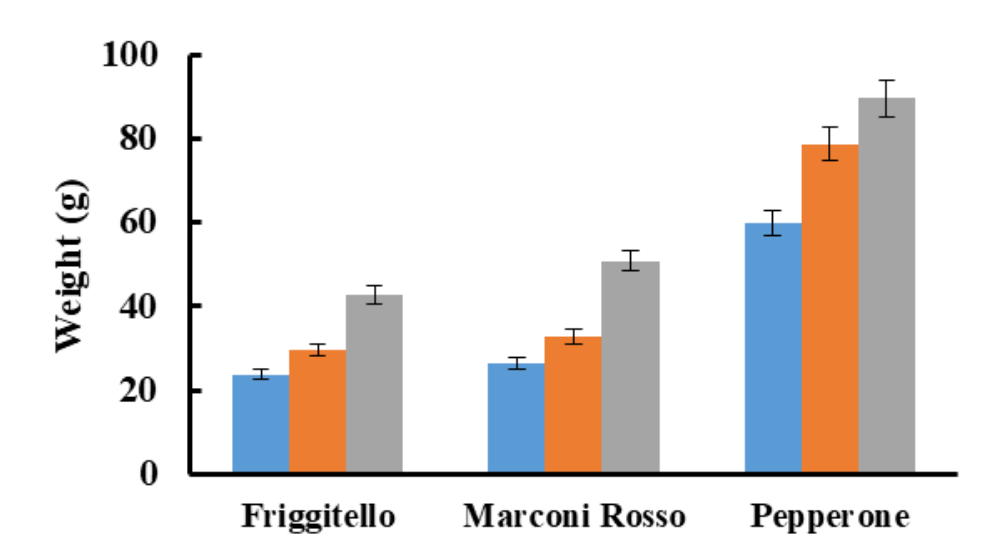

(a)

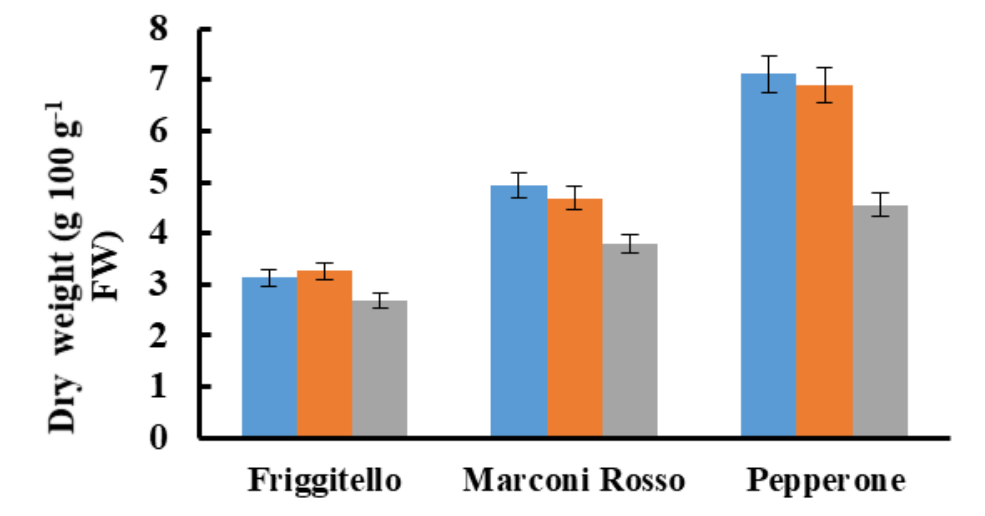

(b)

Fig. 3.2. Effects of water deficit irrigation $\left(\square-100 \mathrm{ml} \mathrm{day}^{-1}\right),\left(\square-200 \mathrm{ml} \mathrm{day}^{-1}\right)$ or full irrigation $400 \mathrm{ml} \mathrm{day}^{-1}$ ) on weight characteristics of fruits of three different C. annuum cultivars; (a) weight (g) and (b) dry matter as a proportion of fresh weight (g $\left.100^{\mathrm{g}-1} \mathrm{FW}\right)$.

The water stress had prominent effect on time taken for anthesis in pepper cultivars. Number of days taken for anthesis ranged between 25.87 and 32.55 days (Table 3.1.). Also, significant difference was observed in days to anthesis (DA), between the water stressed (both $100 \mathrm{~mL} \mathrm{day}^{-1}$ and $200 \mathrm{~mL} \mathrm{day}^{-1}$ ) and fully irrigated plants $\left(400 \mathrm{~mL}\right.$ day $\left.^{-1}\right)$. However, no significant difference was observed in DA 
between the water stressed treatments.

Further, no differences were observed in DA, among the cultivars too. On average, the time to anthesis of all pepper cultivars was delayed by about 5-6 days in both deficit irrigation treatments where number of days taken for anthesis was ranged between $25-26$ in plants, kept in near field capacity of in all three cultivars (Table 3.1.)

In addition, the water stress treatment had exerted significant effect on the days required for the fruit to reach harvest maturity (DHM; Table 2.1.). The DHM was delayed by a week (6.93 days) when plants were grown under water-stressed condition (49.39 days) compared to non-water stressed plants (42.46 days). Further, a significant difference in number of days from anthesis to DHM was observed among the pepper cultivars too (Table 2.1.). Cv. Pepperone, treated with $100 \mathrm{~mL}^{-1}{ }^{-1}$ took 49.69 days for DHM which is significantly higher than that observed for the other cultivars and as well as those treated with $200 \mathrm{~mL}$ day ${ }^{-1}(48.21)$. Nevertheless, no significant differences were observed in DHM between the two water-stressed treatments in cultivars Friggitello and Marconi rosso. Meanwhile, among the non-stressed plants, cv. Friggitello took least number of days (42.90) for harvesting from anthesis compared to cv. Pepperone (43.66). Thereby, under greenhouse condition, cv. Marconi Rosso, was significantly effective in reducing the number of days from anthesis to harvest (47.44) when subjected to drought-stressed condition. However, the maturity of fruits was significantly slower in cv.Pepperone, grown under same stressed conditions (49.69).

Table 3.1. Effects of water deficit irrigation $\left(100 \mathrm{ml} \mathrm{day}^{-1} ; 200 \mathrm{ml} \mathrm{day}^{-1}\right)$ or full irrigation $\left(400 \mathrm{ml} \mathrm{day}^{-1}\right)$ on days to anthesis (DA) and harvest maturity (DHM) of C.annuum fruits of three different cultivars.

\begin{tabular}{|c|c|c|c|c|}
\hline \multicolumn{2}{|c|}{ 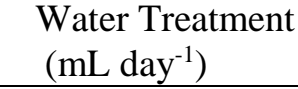 } & Freggitello & Marcone Rosso & Pepperone \\
\hline \multirow[t]{3}{*}{ DA } & 100 & $31.76^{\mathrm{b}}$ & $30.87^{b}$ & $32.55^{\mathrm{b}}$ \\
\hline & 200 & $30.87^{b}$ & $31.56^{\mathrm{b}}$ & $31.47^{\mathrm{b}}$ \\
\hline & 400 & $25.87^{\mathrm{a}}$ & $26.73^{\mathrm{a}}$ & $26.61^{\mathrm{a}}$ \\
\hline \multirow[t]{3}{*}{ DHM } & 100 & $48.20^{\mathrm{b}}$ & $47.44^{\mathrm{b}}$ & $49.69^{c}$ \\
\hline & 200 & $47.64^{\mathrm{b}}$ & $47.78^{\mathrm{b}}$ & $48.21^{\mathrm{b}}$ \\
\hline & 400 & $42.90^{\mathrm{a}}$ & $43.28^{\mathrm{a}}$ & 43.66 \\
\hline
\end{tabular}

Within each column, same letter indicates no significant difference between treatments at 5\% levels.

DA - Days to Anthesis

DHM - Days to Harvest Maturity

\subsection{Effect of DI on overall fruit quality}

The objective colour of each fruit was measured when fruit was judged to be at optimum maturity (when 
turning green to red). $\mathrm{Cv}$. Pepperone showed higher values for lightness $\left(\mathrm{L}^{*}\right)$ and higher hue angle $\left(\mathrm{H}^{\circ}\right)$ for plants receiving $100 \mathrm{ml}$ water per day (Table 3.2) than did for non-water-stressed plants. In addition, lower $\mathrm{C}^{*}$ value (chroma) was observed in the DI plants in all three cultivars. It shows that DI has a significant effect on the objective colour and it depends on the cultivars too.

Table 3.2: Effects of water deficit irrigation $\left(100 \mathrm{ml} \mathrm{day}^{-1} ; 200 \mathrm{ml} \mathrm{day}^{-1}\right)$ or full irrigation $\left(400 \mathrm{ml} \mathrm{day}^{-1}\right)$ on $^{-}$ objective colour ( $\mathrm{L}^{*}$ is lightness, $\mathrm{C}^{*}$ is chroma, and $\mathrm{H}^{0}$ is the hue angle) of primary pepper fruits of three different cultivars. Cultivars are arranged in descending order of $\mathrm{H}^{0}$ values for fully irrigated plants.

\begin{tabular}{lcccccccccc}
\hline Cultivar & & $\mathrm{L}^{*}$ & \multicolumn{5}{c}{$\mathrm{C}^{*}$} & $\mathrm{H}^{0}$ \\
\hline $\begin{array}{l}\text { Water treatment } \\
\text { mL day }^{-1}\end{array}$ & 100 & 200 & 400 & 100 & 200 & 400 & 100 & 200 & 400 \\
\hline Friggittello & $30.65^{\mathrm{a}}$ & $32.77^{\mathrm{a}}$ & $32.64^{\mathrm{a}}$ & $28.32^{\mathrm{a}}$ & $28.33^{\mathrm{b}}$ & $28.76^{\mathrm{b}}$ & $112.27^{\mathrm{b}}$ & $113.69^{\mathrm{a}}$ & $113.82^{\mathrm{a}}$ \\
Marconi Rosso & $30.20^{\mathrm{a}}$ & $31.78^{\mathrm{a}}$ & $32.43^{\mathrm{a}}$ & $28.68^{\mathrm{a}}$ & $28.79^{\mathrm{b}}$ & $29.67^{\mathrm{b}}$ & $113.62^{\mathrm{b}}$ & $112.74^{\mathrm{a}}$ & $112.61^{\mathrm{a}}$ \\
Pepperone & $34.62^{\mathrm{b}}$ & $31.79^{\mathrm{a}}$ & $32.63^{\mathrm{a}}$ & $27.66^{\mathrm{a}}$ & $28.89^{\mathrm{b}}$ & $28.61^{\mathrm{b}}$ & $116.82^{\mathrm{b}}$ & $113.76^{\mathrm{a}}$ & $113.63^{\mathrm{a}}$
\end{tabular}

Within each column, same letter indicates no significant difference between treatments at $5 \%$ levels.

\subsection{Soluble sugars}

Fructose, glucose and sucrose were the three main sugars found in the different cultivars of peppers studied. Further, both on fresh and dry weight basis, concentration of total sugar content did not significantly differ among cultivars. However, on fresh weight basis, except cv. Marconi Rosso, plants treated with less water showed significantly greater sugar content than the plants kept at or near field capacity (Table 3.2). In addition, on dry weight basis, in cv. Pepperone, the total sugar content was increased significantly with the water stress treatment.

Nevertheless, levels of fructose and glucose were similar and sucrose concentration was minimal in all three cultivars. However, there were no significant differences in the total sugar content among the two water stressed treatments $\left(100\right.$ and $200 \mathrm{~mL}$ day $\left.{ }^{-\mathrm{I}}\right)$ in all three cultivars. Nevertheless, the sucrose and fructose contents were increased with water stressed treatment except in cv. Pepperone (Table 3.2).

\subsection{Total Phenols}

As per the results, total phenolics, expressed as gallic acid equivalents (GAEs) was significantly increased on both FW and DW basis with greater degree in DI. Significant difference was observed in the total phenolics per FW and DW among the water -stressed and non-stressed plants from all three cultivars, 
On fresh weight basis, the total phenoilc content in water-stressed plants ranged between $12.33 \mathrm{mg} \mathrm{g}^{-1}$ and $13.17 \mathrm{mg} \mathrm{g}^{-1}$ which is significantly greater than did the non-stressed plants, ranged between $10.79 \mathrm{mg} \mathrm{g}^{-1}$ and $11.62 \mathrm{mg} \mathrm{g}^{-1}$ (Table 3.3.). However, there was no significant difference in the total pholic content between the two deficit irrigation treatments. Similarly, on dry weight basis too, the deficit irrigated plants showed significantly higher amount of total phenolics that ranged between $123.99 \mathrm{mg} \mathrm{g}^{-1}$ and $133.62 \mathrm{mg} \mathrm{g}^{-}$ ${ }^{1}$. Lowest deficit irrigated plants $\left(100 \mathrm{~mL} \mathrm{day}^{-1}\right)$ of all three cultivars contained significantly greater amount of phenolics than that of the plants, treated with either $200 \mathrm{~mL}$ water per day or non-water stressed plants.

Table 3.4. Effects of water deficit irrigation ( $\left.100 \mathrm{ml} \mathrm{day}^{-1}, 200 \mathrm{ml} \mathrm{day}^{-1}\right)$ or full irrigation $\left(400 \mathrm{ml} \mathrm{day}^{-1}\right)$ on concentration of total phenolic content (mg GAE/g )* of pepper cultivars, expressed per fresh weight (FW) and dry weight (DW).

\begin{tabular}{|c|c|c|}
\hline Water Treatment & Freggitello & Marcone Rosso \\
\hline
\end{tabular}

FW

$\begin{array}{lccr}100 & 12.79^{\mathrm{b}} & 12.97^{\mathrm{b}} & 13.17^{\mathrm{b}} \\ 200 & 12.33^{\mathrm{b}} & 12.78^{\mathrm{b}} & 12.74^{\mathrm{b}} \\ 400 & 10.89^{\mathrm{a}} & 10.79^{\mathrm{a}} & 11.62^{\mathrm{a}} \\ 100 & 129.34^{\mathrm{c}} & 130.23^{\mathrm{c}} & 133.62^{\mathrm{c}} \\ 200 & 123.99^{\mathrm{b}} & 124.88^{\mathrm{b}} & 128.92^{\mathrm{b}} \\ 400 & 108.81^{\mathrm{a}} & 112.43^{\mathrm{a}} & 119.97^{\mathrm{a}}\end{array}$

Within each column, same letter indicates no significant difference between treatments at 5\% levels.
$*$ GAE = Gallic acid equivalents 
Moreover, the total phenolic content varies significantly $(\mathrm{p} \leq 0.05)$ among the cultivars too. That is, $\mathrm{cv}$. Pepperone presented higher concentrations of total phenols per FW (13.17 $\mathrm{mg} \mathrm{g}^{-1} \mathrm{FW}$; Table 3.4.) as well as per DW (133.62 $\left.\mathrm{mg} \mathrm{g}^{-1} \mathrm{DW}\right)$ in fruits from plants treated with 100 of water per day. On average, the total phenol concentration ranged approximately 1.1- and 1.2-fold higher in peppers from stressed-plants treated with $100 \mathrm{~mL}$ of water per day, compared to that of $400 \mathrm{~mL}$ (near field capacity). In cvs. Friggitello and Marconi Rosso, the total phenol concentration ranged approximately 1.0- and 1.1 fold higher in water-stressed plants treated with $100 \mathrm{~mL}$ of water per day (Table 3.4.). On FW basis, Cv.Marconi Rosso showed the lowest total phenolic content $\left(10.79 \mathrm{mg} \mathrm{g}^{-1}\right)$ among the three cultivars, investigated. Thereby, the water-stressed treatments (both 100 and $200 \mathrm{~mL}$ water per day) showed a significant increase in total phenolic content in all three cultivars of peppers, used in this study.

\section{Discussion}

Worldwide, successful attempts, have been documented regarding the use of deficit irrigation method to improve irrigation water use efficiency in various crop species. Bell pepper (Capsicum annuum) has been classified as susceptible to water stress, with blossom stage being the most sensitive (Fallik et al., 2019). To obtain high yield, adequate water supply and relatively moist soils are required during the total growing period of bell pepper. The soil water usage was significantly greater for plants treated with $100 \mathrm{~mL}$ of water per day than the plants receiving $200 \mathrm{~mL}$ water per day and the plants kept at or near field capacity. These results were in agreement with Hassan et al., (2021) where the deficit irrigation treatment was found to increase the soil water usage in water-stressed C.annuum plants.

As expected, FW was affected by water stress and was higher in highly irrigated control fruits. Cv. Pepperone showed significantly higher difference in the reduction of FW of the fruits harvested from water-stressed plants. DM was also significantly affected by reduced irrigation. The highest content of DM was observed in low irrigated, cvs. Fri Within each column. same letter indicates no sionificant difference hetween treatments at $5 \%$ levels. Within each column, same letter indicates no significant difference between treatments at $5 \%$ levels.

As far as the harvest maturity and the color change of peppers is concerned, the color change is the most obvious sign of ripening in most fruits. The water stress treatment had exerted significant effect on days to harvest maturity (DHM) from anthesis of pepper varieties (Table 3.1). The DHM was delayed by a week in plants, grown under water-stressed condition compared to non-water stressed plants. Further, a significant difference in number of days from anthesis to DHM was also observed among the pepper cultivars (Table 3.1). Number of days to reach the harvesting maturity of fruits from cv. Pepperone, treated with $100 \mathrm{~mL} \mathrm{day}^{-1}$, 
was greater than the other two cultivars. Nevertheless, no significant differences were observed in DHM between the two water-stressed treatments in cultivars Friggitello and Marconi rosso. Meanwhile, among the non-stressed plants, cv. Friggitello took least number of days for harvesting from anthesis. Thereby, under greenhouse condition, cv. Marconi Rosso, was significantly effective in reducing the number of days from anthesis to harvest when subjected to drought-stressed condition.

On fresh weight basis, the total sugar content did not differ significantly among the cultivars, studied. This result was in agreement with the previous study by Fallik et al., (2019). However, on fresh weight basis, except cv. Marconi Rosso, plants treated with less water showed significantly greater sugar content than the plants kept at or near field capacity (Table 3.3.).

The total sugar content of cv. Pepperone was increased significantly with the water stress treatment. Increases in total soluble carbohydrates of plants exposed to water deficiency are frequently reported (Peña Estevez et al., 2018). However, there were no significant differences in the total sugar content among the two water stressed treatments (100 and $200 \mathrm{~mL}$ day $^{-1}$ ) in all three cultivars during our research. Nevertheless, except cv. Pepperone, sucrose and fructose contents were increased with water stressed treatment in the other two cultivars (Table 3.3.). Thereby, the greater sugar content in DI-treated plants may be an attempt by the plant to reduce osmotic potential by the accumulation of solutes.

In the present work, the total phenol content was determined in three cultivars of bell pepper, with and without deficit irrigation. Results indicated that on dry weight basis, Cv. Pepperone presented higher concentrations of total phenols in the fruits from lowest water-stressed plants. In cv. Pepperone, on average, the total phenol concentration was ranged approximately 1.1- and 1.2-fold higher in peppers from lowest stressed-plants but that of in cvs. Friggitello and Marconi Rosso, were 1.0- and 1.1 fold higher. These values were higher than those reported by Rocha et al., (2018) in red pepper (Capsicum annum) harvested in Yunnan Province, China (with $2.1 \mathrm{mg} / \mathrm{g}$ of fresh tissue) and were in the same range to the results indicated by Fallik et al., (2019) who found levels of 12.89 and $12.9 \mathrm{mg} / \mathrm{g}$ of total phenols in fresh tissue for Mazurca variety red bell peppers and Taranto yellow bell peppers, respectively.

In addition, a significant difference was observed in the total phenolics per FW, among the water-stressed and non-stressed plants from all three cultivars, where, higher total phenolics content (13.17 $\left.\mathrm{mg} \mathrm{g}^{-1} \mathrm{FW}\right)$ was observed in cv. Pepperone than did the cv. Marconi Rosso (12.97 $\left.\mathrm{mg} \mathrm{g}^{-1} \mathrm{FW}\right)$ and cv. Friggitello (12.79 mg $\mathrm{g}^{-1} \mathrm{FW}$ ). Thus, the water-stressed treatments (both 100 and $200 \mathrm{~mL}$ water per day) showed a significant 
increase in total phenolic content in all three cultivars, studied in this experiment.

Many research workers have been paying their attention in altering the irrigation patterns and volumes of irrigated water in pepper cultivation in order to save water in areas, where the water scarcity is a major problem in agriculture. Also, it improves the quality of fruits with the minimum volume of water. Rocha et al., (2018) found in the open field condition, 3-day irrigation interval guaranteed optimum performance of bell pepper in terms of yield.

On conclusion, this study revealed that the deficit irrigation in peppers reduces the fresh weight of the harvested fruits. However, the results also proved that deficit irrigation from flower initiation to fruit harvest lead to better water use efficacy of pepper cultivars, particularly Cv. Marconi Rosso. Further, the results proved that the postharvest quality, importantly the health-benefitting properties of peppers can be enhanced through the water-stress treatment. It leads to more accumulation of sugars as a mechanism to reduce the osmotic potential of the water-stressed plants. Similarly, the phenolic content, reported to have number of health benefitting properties, was also increased in all three cultivars of peppers with the deficit irrigation practice, under glass house condition.

\section{$\underline{\text { References }}$}

1. Abu Glion, H., Alkalai-Tuvia, S., Zaaroor-Presman, M., Chalupowicz, D., Zanbar, M., Amichai, M., Cohen, S., Shemer, T., Sarig, S. and Fallik, E., 2019. Effects of Rootstock/Scion Combination and Two Irrigation Water Qualities on Cherry Tomato Yield and Postharvest Fruit Quality. Horticulturae, 5(2), pp.35.

2. Adeoye, P. A., Adesiji, R. A., Oloruntade, A. J. and Njemanze, C. F. 2014. Effect of Irrigation Intervals on Growth and Yield of Bell Pepper (Capsicum annuum) in a tropical semi-arid region. American Journal of Experimental Agriculture. 4 (5):pp. 515-524.

3. Blanco-Rios, A. K., Medina-Juarez, L. A., Gonzalez-Aguilar, G. A., Gamez-Meza, N. 2013. Antioxidant activity of the phenolic and oily fractions of different sweet bell peppers. Journal of the Mexican Chemical Society 57: pp.137-143. 
4. Bordonaba, J. G. and Terry L. A. 2010. Manipulating the taste-related composition of strawberry fruits (Fragaria $x$ ananassa) from different cultivars using deficit irrigation. Food Chemistry 122: pp.1020-1026.

5. Cui, J., Shao, G., Lu, J., Keabetswe, L. and Hoogenboom, G., 2020. Yield, quality and drought sensitivity of tomato to water deficit during different growth stages. Scientia Agricola, 77(2).

6. Dorji, K. H., Behboudian,M. H. and Zegbe-Domınguez,J. A. 2005. Water relations, growth, yield and fruit quality of hot pepper under deficit irrigation and partial root zone drying. Scientia Horticulture 104:pp.137-149.

7. Durán Zuazo, V., Franco Tarifa, D., Cárceles Rodríguez, B., Gálvez Ruiz, B., Cermeño Sacristán, P., Cuadros Tavira, S. and García-Tejero, I., 2021. Mango fruit quality improvements in response to water stress: implications for adaptation under environmental constraints. Horticultural Science, 48(No. 1), pp.1-11.

8. Fallik, E., Alkalai-Tuvia, S., Chalupowicz, D., Zaaroor-Presman, M., Offenbach, R., Cohen, S. and Tripler, E., 2019. How Water Quality and Quantity Affect Pepper Yield and Postharvest Quality. Horticulturae, 5(1), pp.4.

9. Fereres, E., Soriano, M. A. 2007. Deficit irrigation for reducing agricultural water use. Journal of Experimental Botany, 58 (2): pp.147-159.

10. Ferreira, M., Conceição, N., Malheiro, A., Silvestre, J. and Silva, R., 2017. Water stress indicators and stress functions to calculate soil water depletion in deficit irrigated grapevine and kiwi. Acta Horticulturae, (1150), pp.119-126.

11. Hassan, I., Gaballah, M., El-Hoseiny, H., El-Sharnouby, M. and Alam-Eldein, S., 2021. Deficit Irrigation to Enhance Fruit Quality of the 'African Rose' Plum under the Egyptian Semi-Arid Conditions. Agronomy, 11(7), pp.1405. 
12. Ismail, S.M. 2010. Influence of Deficit Irrigation on Water Use Efficiency and Bird Pepper Production (Capsicum annuum L.) Environmental \& Arid Land Agriculture Science Vol. 21: No. 2, pp: 29-43.

13. Kouassi, K.C., Koffi-Nevry, R. 2012. Evaluation de la connaissance et utilisation des varieties de piment (Capsicum) cultivees en Cote d'Ivoire, International Journal of Biological and Chemical Sciences, 6 (1): pp. 75-185.

14. Malejane, D., Tinyani, P., Soundy, P., Sultanbawa, Y. and Sivakumar, D., 2017. Deficit irrigation improves phenolic content and antioxidant activity in leafy lettuce varieties. Food Science \& Nutrition, 6(2), pp.334-341.

15. Marin, A., Ferreres, F., Tomas-Barberan, F. A., Gil, M. I. 2004. Characterization and quantification of antioxidant constituents of sweet pepper (Capsicum annum, L.) Journal of Agricultural food Chemistry 52: pp. 3861-3869.

16. Martinelli, T. 2008. In situ localization of glucose and sucrose in dehydrating leaves of Sporobolus stapfianus. Journal of Plant Physiology 165: pp.580- 587.

17. Menichini, F., Tundis, R., Bonesi, M., Loizzo, M. R., Conforti, F., Statti G., De Cindio B., Houghton P. J., Menichini F. 2009. The influence of fruit ripening on the phytochemical content and biological activity of Capsicum chinense Jacq. Cv.Habanero. Food Chemistry, 114: pp.553-560.

18. Mueller, M., Hobiger, S., Jungbauer, A. 2010. Anti-inflammatory activity of extracts from fruits, herbs and spices, Food Chemistry, 122: pp.987-996.

19. Nwokem, C. O., Agbaji, E. B., Kagbu, J. A., Ekanem, E. J. 2010. Determination of Capsaicin Content and Pungency Level of Five Different Peppers Grown in Nigeria, New York Science Journal, 3(9): 17-21.

20. Peña Estevez, M., Artés-Hernández, F., Aguayo, E., Artés, F. and Gómez, P., 2018. Postharvest quality of whole and fresh-cut pomegranates cultivated under deficit irrigation. Acta Horticulturae, (1209), pp.265-270. 
21. Rocha, P., Santos, M., Donato, S., Brito, C. and Ávila, J., 2018. Bell pepper cultivation under different irrigation strategies in soil with and without mulching. Horticultura Brasileira, 36(4), pp.453-460.

22. Simmone, A. H., Simmone, E.H., Eitenmiller, R. R., Mills, H. A.Green, N. R. 1997. Ascorbic acid and provitamin A content in some usually coloured bell peppers. Journal of Food Composition and Analysis 10: pp.299-311.

23. Sircelj, H., Tausz, M., Grill, D. and Batic, F. 2005. Biochemical responses in leaves of two apple tree cultivars subjected to progressing drought. Journal of Plant Physiology 162: pp.1318.

24. Singleton, V. L., Rossi, J. A.1965. Colorimetry of total phenolics with phosphomolybdicphosphotungstic acid reagents. American Journal of Enology and Viticulture 16: pp.144-158.

25. Terry, L. A., Chope, G. A. and Bordonoba, J.G. 2007. Effect of Water Deficit Irrigation and Inoculation with Botrytis cinerea on Strawberry (Fragaria x ananassa) Fruit Quality. Journal of Agricultural and Food Chemistry 55:pp. 10812-10819.

26. Venturi, M., Manfrini, L., Perulli, G., Boini, A., Bresilla, K., Corelli Grappadelli, L. and Morandi, B., 2021. Deficit Irrigation as a Tool to Optimize Fruit Quality in Abbé Fetél Pear. Agronomy, 11(6), pp.1141.

27. Wakrim, R., Wahbi, S., Tahi, H., Aganchich, B., Serraj, R. 2005. Comparative effects of partial root drying and regulated deficit irrigation on water relations and water use efficiency in common bean (Phaseolus vulgaris L.). Agriculture, Ecosystems \& Environment 106:pp. 275-287.

28. Yahaya, O., Alao, F., Odigie, C.J. 2012. Yield, crop-water-use evaluation for pepper production under irrigated cultivation in Akure, Nigeria. Global J. Sc. Frontier Res. Agric \& Bio. 12(1): pp.1822.

29. Zhuang, Y., Chen, L., Sun, L., Cao, J. 2012. Bioactive characteristics and antioxidant activities of nine peppers, Journal of Functional Foods 4: pp.331-338. 
30. Zimmer A. R., Leonardi, B., Miron, D., Schapoval, E., Oliveira, J. R., Gosmann, G. 2012. Antioxidant and anti-inflammatory properties of Capsicum baccatum: From traditional use to scientific approach, Journal of Ethnopharmacology, 139 (1): pp.228-233. 